\title{
Y Kuşağı Tüketicilerin Gıda Satın Alma Davranışı
}

\section{Celile Ö. DÖLEKOĞLU ${ }^{\mathscr{B}}$ Onur ÇELIK}

Adana Bilim ve Teknoloji Üniversitesi, Adana

$\varangle$ : codolekoğlu@adanabtu.edu.tr

\section{ÖZET}

Yaşlanan dünya ile birlikte yaşanan gelişmeler birer dönüm noktası olarak adlandırılmaktadır. Sanayi devrimi, büyük buhran, dünya savaşları, teknolojik devrim son 150 yıl için birer çağ özelliği taşımaktadır. Bu çağlar toplumun yaşam tarzında, satın alma davranışında farklılıklar ortaya çıkarmıştır. Bu farklılıkların ortaya konulması karar alıcılardan işletmelerin pazarlama, insan kaynakları, üretim birimleri için önemlidir. Aynı dönemde doğanlar arasında ortak özellikler daha çok arttığı için de her jenerasyon için "yeni nesil" "kuşak" terimi kullanılmaktadır. Her kuşağın kendi değerleri, tutumları, davranışları, sosyal yaşamı, tüketimi, alışkanlıkları, dünya görüşünün farklılığı ret edilemez gerçektir. İçinde bulunduğumuz dönem ise daha çok Y kuşağının hâkim olduğu ve peşinden $Z$ kuşağının geldiği dönemdir. Son 50 yılda dünya genelindeki nüfusun artışı, Y kuşağının büyük ölçüde artmasına ve dünyanın en büyük nüfus payına sahip olmasına neden olmuştur. Genç olan bu tüketici grubunun hızlı tüketim alışkanlıkları içinde gıda ürünleri ve hizmetleri tüketiminin yerini bilmek ve belirlemek de önemlidir. Bu çalışma, tüketicilerin önemli bir kısmını oluşturan bu kuşağın gıda ürünleri satın alma, karar ve davranış özelliklerini genel olarak ortaya koymak amacıyla 8-37 yaş grubunda bulunan ve Adana merkezinde yaşayan 300 kişi ile anket yapılmıştır. Katılımcıların \%50,7'si kadınlardır, \%45,7'si tam zamanlı çalışmaktadır; \%60,7'si haftada en az 1 kez ev dışında yemek yemekte ve ev dışı yemek için katılımcıların \%84'ü 100-500 TL aylık harcama yapmaktadır. Et ağırlıklı geleneksel mutfak (kebap, ciğer, döner vb.) en çok tercih edilen yemek türü olarak belirlenmiştir. Söz konusu örneklem grubu, gıda ürünlerinde yenilikçi olmayan, sağlıklı beslenmeyi sadece söylemde kabul eden ancak gida güvenilirliği ile ilgili bilinçi olan kişilerden oluşmaktadır.

\section{Food Purchasing Behavior of Y Generation Consumers}

\section{ABSTRACT}

Developments in the aging world are called as a milestone. The industrial revolution, the great depression, the world wars, and the technological revolution, all, have been an age characteristic for the last 150 years. These ages have revealed differences in the way of life and buying behavior of society. The determination of these differences is important for the decision-makers of business's, marketing, human resources, production units. Since the common characteristics among the born in the same period the term "new generation" is used for each generation. The reality of each generation is that their values, attitudes, behaviors, social life, consumption, habits, the difference of world view can not be rejected. The period that we live in is dominated by the generation $\mathrm{Y}$ and followed by the $\mathrm{Z}$ generation. In the last 50 years, the increase of population in the world has led to a large increase in the $\mathrm{Y}$ generation and become the $\mathrm{Y}$ generation the world's largest population. It is also important to know and determine the place of consumption of food products and services in the fast
Makale Tarihçesi

Geliş : 23.10.2018

Kabul : 28.12.2018

Anahtar Kelimeler
Yeni Nesil,
Y Kuşağı,
Gıda Tüketimi,
Tüketici Tercihi

Araştırma Makalesi

Article History

Received : 23.10.2018

Accepted : 28.12.2018

\section{Keywords}

New Generation,

Y Generation,

Food Consumption,

Customer Preferences

Research Article 
consumption habits of this young consumer group. In this study, a questionnaire was conducted with 300 people living in the center of Adana in the age of $18-37$ in order to determine the general decision making and behavior of food products of this generation which constitutes a significant part of the consumers. Overall, 50.7\% of the participants are women and $45.7 \%$ are full-time workers; $60.7 \%$ of the participants spend- at least once a week- out of home for food and $84 \%$ of the participants spend 100-500 TL monthly for food. Meat-based traditional cuisine (kebab, liver, doner, etc.) was the most preferred type of food. The sample group consists of people who are not innovative in food products but who accept healthy nutrition only in discourse but who are known conscious about food reliability.

To cite: Dölekoğlu CÖ, Çelik O 2018. Y Kuşağı Tüketicilerin Gıda Satın Alma Davranışı. KSÜ Tar Doğa Derg 21(Özel Sayı) : 55-66, DOI : 10.18016/ ksutarimdoga.vi.474049

\section{GİRIŞ}

İnsanlar doğduklarında aynı mekân olmasa da aynı zaman dilimi içerisinde dünyaya gelmiş diğer bütün insanların oluşturduğu toplumun bir parçasıdır (Çinkılıç, 2018). Aynı zaman diliminde dünyaya gelen insanlar aynı olaylardan ve gelişmelerden benzer şekilde etkilenmektedir. İnsanlığın daha sistematik bir şekilde irdelenebilmesi amaçlı yakın özellikler gösteren kitleleri sınıflandırılmış ve kuşak olarak nitelendirilmiştir. Kuşak kavramı benzer anlamlarda olmasa da "kohort" kavramı ile ilişkilendirilmektedir. Ortak paydada birleşen bireyler kohort kavramı ile ifade edilir. Bu da kuşak kavramının anlamı ile örtüşmektedir (Çetin ve Karalar, 2016). Nitekim Türk Dil Kurumu Felsefe Terimi olarak kuşak kavramını "yaklaşık olarak aynı yıllarda doğmuş, aynı çă̆ın şartlarını, dolayısıyla birbirine benzer sıkıntıları, kaderleri paylaşmış, benzer ödevlerle yükümlü olmuş kişilerin topluluğu" olarak tanımlamaktadır (TDK 19.09.2018). Kuşaklar, aynı zaman aralığında doğmuş, yaşadıkları zamanın sosyal, ekonomik, kültürel, siyasal olayları ve hâkim değerlerinden etkilenmiş kişi ve topluluklardır (Altuntuğ, 2012). Her kuşağın kendi değerleri, tutumları, davranışları, gelenekleri, motivasyonları, yetki algısı, liderlik beklentileri olduğu genel olarak kabul edilmektedir (Crampton ve Hodge, 2007; Aktaran Çelik ve Gürcüoğlu, 2016; Dries ve ark, 2008).

İlk kuşak kavramı II. Dünya savaşı sonrasında ortaya atılmıştır. Savaş süresi ve sonrasında nüfus artış hızının yükselmesi bu dönemin (1946-1964) Baby Bummer-olarak adlandırılmasına neden olmuştur. Kuzey Amerika-İngiliz terimi olan "baby boom" yıllık doğum hızında büyük artış anlamına gelmektedir ve bu dönemde ABD'de 78,2 milyon doğum yaşanmıştır (www.acikbilim.com). Bu dönem öncesi (1925-1946) gelenekçiler olarak adlandırılmıştır (Yüksekbilgili, 2013). 1965-1980 arası doğumlular için de X kuşağı terimi kullanılmıştır. X kuşağı Babby Boomer'ların özgürlükçü havasını taşıyan ve farklılıktan hoşlanan, ön yargılı olmayan, romantik ve sağduyulu bir nesil olarak hatırlanmaktadır (www.indigodergisi.com). Y kuşağı (1980-2000) günümüz nüfusunun en yüksek oranını kapsayan, iş yaşamının aktif çalışanları ve adaylarını içeren ve aynı zamanda büyük bir tüketici grubu olan kuşaktır. 2000'den sonra doğanlar da Z kuşağ ${ }_{1}$ olarak kabul edilmektedir. Ancak, literatürde kuşakların ayrımında farklı yıllarla tanımlandığı da görülmektedir. Çünkü kuşakların sinıflandırılmasında bir çok farklı görüş mevcuttur. Sago (2000) iki ana temel faktörü dikkate almıştır; doğum oranı ve aynı dönemde gerçekleşen olaylar. Bir kuşağın başlangıç dönemini doğum oranının artması ve benzer düzeyde devam etmesi belirlerken, kuşağın sona erişini ise doğum oranının azalması belirlemektedir (Barutçu ve Sarıtaş, 2016, 3). Ancak farklı görüşlere göre kuşak sinıflandırılmasında sadece doğum zamanlarını dikkate almak sinırlı olacağı kanısındadır. Düşünce yapısı, hissettikleri, yaşanan olaylar ve tecrübeler de kuşakların sinıflandırılmasında dikkate alınmaktadır (http://www.humanica.com.tr/kusaklari-anlamakyonetmek/ 25.09.2018).

Sessiz/Gelenekselci Kuşak olarak adlandırılan bu nesil birinci ve ikinci dünya savaşlarını yaşamıştır. $\mathrm{Bu}$ sebeple otoriteye boyun eğen, liderlerine bağıml kişilerden oluşmaktadır. Şikayet etmek yerine kurallara uyum sağlarlar (Etlican, 2012). Türkiye Cumhuriyeti’nin kuruluş yıllarında yaşamış olan bu kuşak genel olarak "uyumlu" olarak nitelendirilmektedir (Adıgüzel ve ark., 2014).

Baby Boomers/Patlama Kuşağı dünya savaşlarının sona ermesi ile doğan kuşağa verilen isimdir. Bu sebeple Soğuk Savaş dönemi çocukları olarak da bilinmektedir (Keleş, 2013). Dünya savaşlarından sonrasinda refah düzeyinin artması ile nüfusun çoğalmaya başladığı dönemde dünyaya gelmişlerdir. $\mathrm{Bu}$ nesil sayı olarak fazla olduğu için toplumları şekillendirdiği düşünülmektedir (Zemke vd., 2000). Çalışkan bir nesil olarak kabul edilen bu kuşak mensupları sosyal kurumlara saygı gösterilmesine 
önem verir ve grup çalışmalarına yatkındırlar (Mengi, 2009; Dereli ve Toruntay 2015).

X Kuşağı teknolojideki gelişmelerin hayatımıza direk etki ettiğine şahit olan bir geçiş neslidir (Levickaite, 2010). Bu kuşağın bireyleri genellikle rekabetçi olarak adlandırilır (Bayhan, 2014). Bunun sebebi ise erken yaşta ekonomik sorumluluklar alıp, ailesinin geçim yükünü üstlenmesi ve genç yaşlarda yetişkin rollerine bürünmesidir (Raines, 2002). X kuşağı TV kanallarının açıldığı, tüketimin hızla artmaya başladığı bir döneme denk gelmelerine (Engizek ve Şekerkaya, 2016) rağmen kanaatkar bir nesil olarak bilinirler.

Y Kuşağı digital bir nesil olarak adlandırılan Y kuşağı doğdukları andan itibaren gelişen ve değişen teknolojiyi hayatlarının içerisine alarak yaşamaktadır (Galentine, 2013). Y kuşağı çeşitliliğe saygı duyan, emir almak yerine işbirliği eğilimi olan, olaylara bakış açısı olarak pragmatik bireylerden oluşur (Reeves ve Oh 2008). Geleceği düşünmektense ana odaklanmayı tercih ederler (Yüksekbilgili, 2013). Bu kuşak, girişimci, sabırsız, bireyci, sonuca odaklı, teknoloji ile yüksek bağı olan, hızlı tüketici, internet tutkulu, egosu ve özgüveni yüksek olarak tanımlanmaktadır (Altuntuğ, 2012). Y kuşağı karışık keyiflere ve karışık alışveriş davranışlarına sahip bir kuşak olmasının yanı sıra tüketim odaklı olmaları ile de dikkat çekmektedir (Holtshausen ve Styrdom, 2006; Wolburg ve Pokrywczynski, 2001). Tüketim konusunda en çok ilgi duydukları ürün çeşitleri; giyim, ayakkabı, mobilya, spor malzemeleri, otomobil, aksesuar ve eğlencedir (Williams ve Page, 2011).Y kuşağına dahil tüketicilerin kendilerinden önceki kuşaklardan farklı tüketim alışkanlıkları vardır. Harcayabileceklerinden daha fazla paraya sahip olmaları ve tüketim odaklı bir toplumda dünyaya gelmiş olmaları bu farklılıklarında önemli etkenlerdir (Mandhlazi ve ark., 2013).

Z Kuşağı 2000-2020 yılları arasında dünyaya gelmiş veya gelecek olan insanların oluşturduğu kuşaktır. Y kuşağı ile ortak noktaları fazladır. İnternet kuşağı, kristal kuşak, google kuşağı, .com kuşağı gibi isim yakıştırmaları da yapılmaktadır (Çetin ve Karalar, 2016). Z kuşağının en belirgin özelliği teknolojinin içerisinde doğmuş olmalarıdır. Teknoloji ile doğan ve ilerlemesine şahitlik eden bu kuşak teknolojik aletlerin kullanımı konusunda çok iyilerdir (Berkup, 2014).

Bazı kuşaklar arasında kesin ve net ayrımların olması bazı kuşaklar arasında ise benzerliklerin varlığı başta davranış bilimleri olmak üzere tüm bilim dallarının ilgisinin süregelmesine neden olmuştur. Araştırmalarla kuşakların kendi içinde ortak davranış, tutum, algı, beklenti ve motivasyonu belirlenirken, elde edilen bulgular da tüm alanlarda yaşamın biçimlenmesini sağlamıştır ve sağlamaya da devam etmektedir.
Kuşakları birbirinden ayıran özellikler aynı zamanda o dönemin işgücü piyasası, üreticiler, eğitimciler ve karar alıcıların da önem verdiği bir konu olmuştur. Kuşakların kendi içinde satın alma davranışları da yaşadıkları dönemin sunduğu imkânlara ve toplumun değer yargılarına göre şekillenmiştir. Kuşakların etkilendiği ve etkilediği süreçler, olgular özellikle tüketicinin kral olduğu yıllardan sonra pazarlama kararı verenler için önemli bilgilerdir. Günümüz en büyük nüfusuna sahip kuşağın davranış, tutum ve algilarını belirlemek her alanda daha da önemli olmuştur. Y kuşağı dünyada ve Türkiye'de önemli bir tüketici grubunu temsil etmektedir. Nitekim dünyada yaklaşık 2 milyar olan $\mathrm{Y}$ kuşağ (https://businessht.bloomberght.com 21.09.2018), Türkiye'de de yaklaşık 25.5 milyon ile nüfusun büyük bir oranını temsil etmektedir (http://www.tuik.gov.tr 21.09.2018). Sayısal çoğunluğun yanı sıra Y kuşağının aktif nüfusu oluşturması ve bunun en az çeyrek yüzyıl devam edeceği gerçeği bu kuşakla ilgili çalışmaların artması ve çeşitlenmesine nedendir. Marka sadakati yüksek olan bu tüketici grubunun ilgisini çekmek ve sadakatini kazanmak tüm işletmeler için geleceğin alıcılarını garanti altına almayı ifade etmektedir. Yaşamları süresince ekonomik, sosyal ve kültürel değişimlere şahitlik eden bu kuşak tüketici davranışları ve tüketim kararları açısından topluma etkileri tahminlerin ötesindedir. Diğer kuşakların oluşturmuş oldukları pazarlama ve tüketim alışkanlıklarını temelden değiştirecek ve yeni bir tüketici profilini şekillendireceği düşünülmektedir (Altundağ, 2012). Bu nedenle bu kuşağın farklı mal ve hizmet tercihinde davranış ve algılarını ortaya koyan çalışmalar giderek artmaktadır. Ancak, işgücü piyasası ve davranış bilimleri çalışmalarına nazaran daha az sayıda çalışmaya rastlanmaktadır; Tüketim motivasyonu (Martin and Turley, 2004; Valentine ve Powers, 2013; Shim ve ark., 2011) marka bağllı̆̆g (Gurău, 2012; Foscht ve ark., 2009; Lazarevic, 2012; Giovannini ve ark., 2015; Lazarevic ve Lazarevic, 2007; Yang ve Lau, 2015; Ördün, 2015) satış tutundurmaya yönelik algı ve tutumları (Okan ve Yalman, 2013) ve çeşitli mal ve hizmetlerde tüketim alışkanlıkları ve davranışları (Braunstein ve Zhang, 2005; Sullivan ve Heitmeyer, 2008; Bakewell ve Mitchell, 2003; O'Cass, ve Choy, 2008, Parment, 2013; Hanzaee, ve Aghasibeig, 2008 Lissitsa ve Kol, 2016; Ilgaz, 2018; Altuntuğ 2012; Bayrakdaroğlu1 ve Çakır, 2016; Sarıtaş ve Barutçu, 2016; Yaşa ve Bozkurt, 2012; Kavalcı ve Ünal, 2016 Kılıç ve Kılıç 2017). Teknolojiyi en yüksek düzeyde kullanan bir kuşak olduğu için de bu alandaki mal ve hizmetleri satın alma davranış (Kumar ve Lim, 2008; Chuah ve ark., 2017; Kuyucu, 2014; Yaşa ve Bozyiğit, 2012; Djamasbi ve ark., 2010; Karahisa, 2013; Ustakara, 2015), tüketim kararında sosyal medya kullanım (Bilgihan ve ark, 2013; Nusair ve ark., 2013; Park ve ark., 2009; Casalo ve ark., 2008; Kwon ve Wen, 2010; Lester ve ark., 2006; Sarı ve ark., 
2016; Tingley, 2015; Sharifi fard ve ark, 2016; Bolton ve ark., 2013) çalışmaları mevcuttur. Turizm algısı ve tercihi (Nusiar ve ark., 2011; Akten, 2016; Bilgihan, 2016; Başgöze ve Bayar,2014; Dursun ve Eriş, 2018) de bir diğer ele alınan konudur.

Araştırmalar Y kuşağının gida zincirinin en üstünde yer almasına rağmen (O'Donnell, 2006) kısıtlı sayıda kuşakların zorunlu tüketim maddesi olan gıda tüketimleri ve beslenme alışkanlıklarına ilişkin çalışmalara rastlamak da mümkündür. Jang ve ark. (2011) ABD'de 17-30 yaş arasındaki üniversite öğrencilerinin yeşil restoran tercihlerine yönelik algıları ve tutumları; Muller (2016) araştırmasında Y kuşağının alkol tüketimi ve bunu etkileyen güdüleri ele almıştır. Khalek ve İsmail (2015), Malezya'da kentlerde yaşayan $\mathrm{Y}$ kuşağının helal gıda tüketimlerini; Ling ve ark., (2011) Malezya'da Y Kuşağı Fast-Food tüketiminde müşteri sadakatini araştırmışlardır. Stafleu ve ark., (2011) kadınların beslenme alışkanlıklarını 3 kuşak çerçevesinde (çocuk, anne ve büyükanne) ele alarak kuşaklar arası aktarım ve geçişleri irdelemişlerdir. Teng ve Wang (2013) Tayvan'da üç büyükşehirde süpermarketler ve sağlıkgıda mağazalarından alışveriş yapan 18 ile 70 yaşlarındaki müşterilerin organik gida tüketimlerini incelerken, yaş gruplarında farklılıkları da araştırmışlardır. Belçika'da 19-22 yaş aralığındaki genç nüfusun gida tüketim alışkanlığı (Vermeir ve Verbeke, 2008) belirlemişlerdir. Kim ve Jang (2014) Y kuşağının maddi destek ve sinırlı gelirlere sahip olmasına rağmen neden lüks gida hizmetlerini satın alma yaşam tarzlarını sürdürdüğünü ele almış ve kadınların halka açık tüketim alanlarında daha fazla harcama yapma eğiliminde olduğunu belirlemişlerdir.

Türkiye'de kuşaklarla ile ilgili tüketim çalışmalarının varlığına karşın gida tüketimi ile ilgili çalışmalar oransal olarak azdır. Pekmezci (2017) Ankara'da yaşayan 18-71 yaş arası 500 evli kadın ve erkekle yaptığı araştırmada etnik gıda ürünlerinde kuşaklar arasında tüketim davranışında farklılıkları ele almıştır. Konyar (2017) yaşla birlikte ortaya çıkan etik gıda tüketimi tercihlerini ortaya çıkarmak için İstanbul'da 96 katılımcı ile yaptığı çalışmasında dolaylı olarak kuşakların bu açıdan farklılığını da belirlemiştir. Doğan ve arkadaşları 2018'de Baby Boomer, $\mathrm{X}$ ve $\mathrm{Y}$ kuşaklarının otellerde sunulan yiyecek-içecek hizmetlerinden beklentilerinin farklılık olup olmadığını araştırmışlar ve Baby Boomer kuşağının yiyecek ve içeceklerin çeşitliliği ve lezzeti ile sunulan hizmetlerin kalitesinden diğer kuşaklara göre daha memnun olduklarını belirlemişlerdir. Traş ve Şengül (2017), 2002-2005 yıllarına ait Türkiye'de hane halkı ev dışı gıda tüketim değerleri ile yaş, kuşak ve yıl etkilerini araştırmışlardır. Kılıç ve Şanlıer (2007) $142 \mathrm{kız} \mathrm{öğrenci,} \mathrm{anneleri} \mathrm{ve} \mathrm{anneannelerinin} \mathrm{beslenme}$ alışkanlıklarını Ankara ilinde araştırmış ve kuşaklar arasında anlamlı farklılıklar olduğunu ortaya koymuşlardır; Danışman ve Gündüz (2018)'de X ve Y kuşaklarının dışarıdan kahvaltı satın alma davranış farklılıkları ortaya koymuşlardır.

Bu çalışma Y kuşağının gıda tüketim alışkanlıklarına genel perspektiften bakarak, sözkonusu kuşağın gida ürünleri satın alma karar ve davranışları yanı sıra beslenme alışkanlıklarına ilişkin veriler sunmaktadır.

\section{MATERYAL ve YÖNTEM}

Araştırmanın ana materyalini, Y kuşağı için kabul edilen temel ortak özelliklerinden oluşturulan ölçek soruları ve araştırmacılar tarafından geliştirilen gıda tüketimlerine ilişkin bilgi formundan oluşan anket verileri oluşturmaktadır.

Araştırma uzayı Adana şehir merkezinde yaşayan 1980-2000 doğumlu kişilerden oluşmaktadır. Örnekleme çerçevesinin belirlenmesinin zor ya da imkânsız olduğu durumlarda tercih edilen ihtimalsiz örnekleme yöntemlerinden (Nakip, 2006) kolayda örnekleme yöntemi kullanılmıştır.

Doğru sonuçlara ulaşmak uygun örnek hacminin belirlenmesi ile mümkündür. Pazarlama araştırmalarında araştırma türüne göre kabul görmüş ve uygulanan örnek hacimleri belirlenmiştir. $\mathrm{Bu}$ tür pazar testi, tüketici testi çalışmaları için de 300-500 arasında örnek hacminin kullanılmasinın uygun olduğu belirtilmektedir (Malhotra ve Birks, 2000; aktaran: Gegez, 2010). Ayrica ana kitle 100 binden büyük ve ana kitleye ilişkin bilgi mevcut olduğunda araştırmacılar amaç ve araştırma sürecini dikkate alarak örnek hacmine karar verebilir ve seçilen örnek hacminin \% kaç hata payı ile ana kitleyi temsil ettiği bulunabilir. Adana il nüfus müdürlügü ve TÜİK kayıtlarına göre 2017 yılında Adana merkez ilçelerde 17-37 yaş arasında yaklaşık nüfusun 674 bin olduğu tahmin edilmektedir. Belirli bir güven aralığında hata payı aşağıda verilen formül ile hesaplanabilir (Laajimi ve Briz, 1992; Aktaran, Şengül, ve ark., 1998).

$$
\mathrm{n}=\frac{z^{2} * \mathrm{p} * \mathrm{q}}{\mathrm{e}^{2}}
$$

$\mathrm{p}$ : incelenen birimin ana kitle içinde gerçekleşme olasılığı ( bu çalışmada daha önce benzer bir çalışma olmadığı için popülasyonu temsil edecek maksimum örneğe ulaşmak için oran \%50 alınmıştır)

$$
\begin{aligned}
& \text { q: 1-p } \\
& \text { n:300 } \\
& \text { e: hata terimi } \\
& \text { z: \%95 (\%95 güven aralığ } \\
& \qquad e=\frac{\sqrt{Z^{2} * \mathrm{p} * \mathrm{q}}}{\mathrm{n}}
\end{aligned}
$$$$
\text { z: \%95 (\%95 güven aralığı tablo değeri=1,96) }
$$ 


$$
\mathrm{e}=\frac{\sqrt{1,962^{2} * 0,50 * 0,50}}{300}
$$

$$
\mathrm{e}=0,056
$$

Örnek büyüklügü \%95 önem düzeyinde ana kitleden en fazla \%5,6 sapma gösterecektir. Verilerin analizinde, temel tanımlayıcı istatistiklerle birlikte değişkenler arasında ilişkiler belirlenmiştir.

5’li Likert ölçeğinde katılımcılara sunulan gida ve beslenmeye ilişkin önermelere faktör analizi uygulanmıştır. Faktör analizi, birbiriyle ilişkili olan, fakat büyük ölçüde değişkenlerin diğer alt kümelerinden bağımsız olan değişkenler, faktörler olarak birleştirilir. Dolayısı ile çok sayıda değişken daha az sayıda değişken olarak ifade edilebilir. Böylece, gözlenen değişkenler arasındaki ilişki az ve öz bir şekilde tanımlanır ya da temel süreçlerle ilgili bir kuram test edilebilir (Tabachnick ve Fidell, 2015). Bu çalışmada, Y kuşağının gıda satın alma tutumlarının sosyo-demografik değişkenlerle ilişkisinin varlığını/farklılık gösterip göstermediğini test etmek için faktör analizi yapılmıştır. Elde edilen faktörleri oluşturan önermelerin ortalamaları dikkate alınarak ve bu ortalamalar bağımlı değişken olarak hipotez testleri yapılmıştır. Bağımlı değişken olan gıda seçiciliği ve sağlıklı beslenme ortalamalarını oluşturan veri setinin normallik varsayımını sağlayıp sağlamadiğı test edilmiştir. Verilerin normal dağılıma uygunluğunu belirlemek için Ki-Kare, KolmogorowSmirnov, Lilliefors ve Shapiro - Wilkis analizlerinden yararlanılmaktadır. Bu istatistiklerden KolmogorowSmirnov ve Shapiro - Wilkis en yaygin kullanılanlarıdır (Hair vd., 1992). Testin anlamlılık derecesi 0,05'den daha küçük ise verinin normal dağılım göstermediği sonucuna varılır. Çalışmada yapılan normallik testi $<0,05$ olduğu için normallik hipotezi ret edilmiştir, dağılım normal değildir.

Değişkenler normallik varsayımını sağlamadığı için non-parametrik (Kruskal-Wallis ve Mann Withney U) testler yapılmıştır. Kruskal-Wallis testi, normal dağılım göstermeyen gruplarda üç veya daha fazla sayıda örnek değerin benzer yapıda olup olmadığını test etmek amaciyla kullanılır (Nakip, 2006). One-Way ANOVA'nın non-parametrik karşılığıdır. Mann Withney U testi, parametrik olmayan " $\mathrm{t}$ " testidir ve normal dağılım özelliği göstermeyen bir dağılımda iki bağımsız grup ortalamalarını karşılaştırmak amacıyla kullanılır (Yazıcıŏlu ve Erdoğan, 2004).

\section{Araştırmanın Hipotezleri}

H1: Cinsiyet ile gıda seçiciliği arasında fark anlamlı değildir.

H2: Cinsiyet ile sağllklı beslenme arasında fark anlamlı değildir.

H3: Çalışma durumu ile gıda seçiciliği arasında fark anlamlı değildir.
H4: Çalışma durumu ile sağlıklı beslenme arasında fark anlamlı değildir.

H5: Eğitim ile gıda seçiciliği arasında fark anlamlı değildir.

H6: Eğitim ile sağlıklı beslenme arasında fark anlamlı değildir.

H7: Yaş ile gıda seçiciliği arasında fark anlamlı değildir.

H8: Yaş ile sağlıklı beslenme arasında fark anlamlı değildir.

H9: Gelir ile gıda seçiciliği arasında fark anlamlı değildir.

H10: Gelir ile sağlıklı beslenme arasında fark anlamlı değildir.

H11: Ev dışı gıda tüketim sıklığ̣ ile gıda seçiciliğ arasında fark anlamlı değildir.

H12: Ev dışı gıda tüketim sıklığı ile sağlıklı beslenme arasında fark anlamlı değildir.

\section{ARAŞTIRMA BULGULARI}

Araştırmada denekler eşit sayıda temsiliyet olması amacıyla 151 kadın ve 151 erkek ile anket yapılmıştır. Ancak 2 erkek ile yapılan anket hatalı ve eksik veri içerdiği için değerlendirme dışı bırakılmıştır. Ortalama yaş 28,1'dir ve Nusair ve ark., (2013) yaş siniflandirması dikkate alınarak yapılan gruplandırmada katılımcıların \%57,3’ü 27 yaş üzerindedir. Hedef kitlenin yaş grubu özelliği nedeni ile lise eğitiminde olan birey sayısı yüksek bulunmuştur. Anket Adana ili merkez ilçelerinde oransal dağılımla yapılmıştır ve göçle gelen, gelir düzeyi düşük mahallelerden örnekleme alınmıştır. $\mathrm{Bu}$ geniş yelpaze de farklı eğitim düzeyinde bireyleri araştırmaya dahil etmiştir. Yarı zamanlı çalışanlar da dahil edildiğinde çalışma oranı $\% 54,3$ 'dür ve buna bağlı olarak da katılımcıların \%85,3'nün kişisel gelirinin 3000 TL'nin altında olması doğal bir sonuç olarak değerlendirilebilir (Tablo 1).

İletişim araçlarının televizyon ve gazete dışına çıkması ve sosyal medya kullanımının Y kuşağının vazgeçilmezi olması tüketim davranışını yakından etkilemektedir.

Postmodern olan bu tüketiciler salt tüketimden çok mal ve hizmetle birlikte sembolleri ve imajı da satın almaktadır. Aynı zamanda hızlı tüketici olan Y kuşağı materyalist bir toplumda sosyalleştiği için zenginlik ve satın alma gücünü sergileme eğilimindedirler (Bakewell ve Mitchell, 2003; O'Cassand Frost, 2002. Aktaran: Kim ve Jang, 2014). Günümüz çocuk ve gençleri ebeveynlerinin sahip oldukları bilgi birikimine hali hazırda sahip oldukları için farklı arayışlar içinde (Tükel, 2014) yeme içme kültürlerini de etkilemektedir. Kılı̧̧ ve Şanlıer (2007) kız çocuklarının \% 61.9'u en çok evin dışında yemek yemektedirler. 
Tablo 1. Tanımlayıcı istatistikler

\begin{tabular}{|c|c|c|c|c|c|}
\hline \multirow{3}{*}{ Cinsiyet } & \multicolumn{3}{|c|}{$\%$} & & \multirow[t]{2}{*}{$\%$} \\
\hline & $\mathrm{K}$ & 50,7 & & & \\
\hline & $\mathrm{E}$ & 49,3 & & & \\
\hline \multirow{4}{*}{ Eğitim } & Okur-yazar ve ilkokul & 15,0 & \multirow{4}{*}{ Çalışma } & Tam zamanlı & 45,7 \\
\hline & Ortaokul & 23,7 & & Yarı zamanlı & 7,7 \\
\hline & Lise & 38,3 & & Calıșmiyor & 46,6 \\
\hline & Lisans ve Lisansüstü & 23,0 & & & \\
\hline \multirow{6}{*}{ Yaş } & $<18$ & 11,7 & \multirow{6}{*}{ Gelir } & 1500 den az & 44,0 \\
\hline & $19-20$ & 7,0 & & $1500-3000$ & 41,3 \\
\hline & $21-22$ & 9,0 & & $3000-5000$ & 9,3 \\
\hline & $23-24$ & 7,3 & & $5001-7000$ & 2,0 \\
\hline & $25-26$ & 7,7 & & $7001-10000$ & 0,7 \\
\hline & $>27$ & 57,3 & & 10001 ve üzeri & 2,7 \\
\hline
\end{tabular}

Annelerin \%42.2'si evin dışında bazen yemek yedikleri, anneannelerin ise \% 48,6'sı hiç evin dışında yemek yemediklerini belirtmişler ve kuşaklar arasında anlamlı farklılık olduğunu açıklamışlardır. Sosyal yaşam tarzının bir göstergesi, popüler kültürün bir öğesi, bir sınıfa ait olma arzusu, farklılık arayışı ve genç kuşağın kendini ifade etme aracı olarak gıda ürünleri tüketimi önemli bir unsurdur. Bunu durum ev dışında gıda tüketimini artırmaktadır. Tüketim toplumu tanımlamasindan gida hizmeti sunan restoran ver kafeler de payını almaktadır. Ev dışında gıda tüketimi giderek artmaktadır. Araştırmada katılımclarin \%54,7'sinin haftada en az $1 \mathrm{kez}$ ev dışında yemek yediği ve ortalama aylık harcamalarının 300-500 TL arasında yoğunlaştığ $(\% 47,7)$ belirlenmiştir (Tablo 2). Ev dışı yemek tüketiminde öğünlerde tercihler de sorgulanmış ve öğlen yemeklerinde daha hızlı, yaygın ve pratik olması nedeni ile fast-food tüketimi; akşam yemeği ise daha uzun zaman geçirme süreci olduğu için ev yemekleri
$(\% 34,3)$ ve geleneksel Türk mutfağı $(\% 31,7)$ tercih edilmektedir. Türk yemek kültürünün bir parçası olan sokak yemekleri Adana'da sadece akşamları tercih edilmektedir (Tablo 3). Ekonomik ve demografik faktörler dışında yaşadığımız coğrafyanın doğal kaynakları, aile, içinde bulunduğumuz kültür ve alt kültür, inançlarımız ve yakın çevremiz gıda tüketimimizi doğrudan etkileyen faktörlerdir.

Nitekim beslenme bilgimizi çoğunlukla ailemizden almaktayız ve etkilenmekteyiz (Stafleu ve ark., 1995; Kılıç ve Şanlıer, 2007; Jingxiong ve ark., 2007; Rhodes ve ark., 2016). Özellikle yaşadığımız coğrafyanın ekolojik varlığı ve tarımsal üretimi o coğrafyanın, yörenin yemek alışkanlıklarını da doğrudan etkilemekte ve kuşaklar arasında da alışkanlıklar aktarılmaktadır. Adana ilinde Y kuşağında bölgenin mutfak kültürüne uygun bulgular elde edilmiştir ve geleneksel et ağırlıklı yemek tercihi öne çıkmaktadır (Tablo 4).

Tablo 2. Ev dışı gıda tüketim sıklığı ve aylık harcama

\begin{tabular}{lclc}
\hline Tüketim sıklığı & \% & Harcama grupları & \% \\
\hline Haftada bir kez & 26,7 & 100 'den az & 22,3 \\
Haftada bir kaç kez & 28,0 & $101-300$ & 14,0 \\
Ayda bir kez & 20,7 & $301-500$ & 47,7 \\
Her gün & 6,0 & $501-700$ & 0,7 \\
Özel günlerde (yılda bir kaç kez) & 18,7 & $701-1000$ & 12,3 \\
& & 1001 'den fazla & 3,0 \\
\hline
\end{tabular}

Tablo 3. Ev Dışında Öğünlere Göre Yemek Türü Tercihleri (\%)

\begin{tabular}{lrrr}
\hline & Sabah & Öğlen & Akşam \\
\hline Ev yemekleri & 6,8 & 34 & 34,3 \\
Fast Food & 3,4 & 40,3 & 5,3 \\
Kebap, ciğer, 1zgara & 1,0 & 12 & 31,7 \\
Sokak yemekleri (kokoreç, midye, hotdog vb.) & - & - & 18,3 \\
Balık ve deniz ürünleri & - & 0,3 & 7,3 \\
Unlu mamuller/pastacılık ürünleri & $\mathbf{6 6 , 8}$ & - & - \\
Atıştırmalıklar & 21,6 & 13 & 2,7 \\
Dünya mutfağ1 & 0,3 & 0,3 & 0,3 \\
\hline
\end{tabular}


Tablo 4. Y Kuşağının Mutfak kültürü

\begin{tabular}{lcc} 
& F & \% \\
\hline Et ağırlıklı geleneksel mutfak (kebap-ciğer-döner vb) & 139 & 46,3 \\
Sebze ağırlıklı geleneksel mutfak & 108 & 36,0 \\
Fast-food & 50 & 16,7 \\
Tahıl ağırlıklı geleneksel mutfak & 2 & 0,7 \\
Akdeniz mutfağı & 1 & 0,3 \\
\hline
\end{tabular}

Araştırmada katılımcıların gıda ürünlerinde satın alma eğilimlerini belirmek için 5’li Likert ölçeğinde önermeler sorulmuş ve bu önermeler yapılan faktör analizi ile 2 grupta toplanmıştır. İki faktör toplam varyansın \%55,2'sini açıklamaktadır. Faktörler "gıda seçiciliği" ve "sağlıklı beslenme" olarak adlandırılmıştır. Gıda seçiciliği faktörün toplam varyanstaki değişimin \%35,807'sini açıklarken, sağlıklı beslenme faktörü ise toplam varyansın \%19,407'sini açılamıştır. Güvenilirlik testine bakıldığına ise gıda seçiciliği faktörünün Cronbach's Alfa değeri 0,846 elde edilirken, sağlıklı beslenme faktörünün ise 0,772 olarak elde edilmiştir (Tablo 5).
Tüketicilerin bu iki grupla olan farklılıkları cinsiyet, çalışma durumu Mann Withney U; eğitim, yaş, gelir ve ev dışı gıda tüketim sıklığı da Kruskal Wallis ile test edilmiştir (Tablo 6). Test sonuçlarına göre gıda seçiciliği ile çalışma, eğitim, gelir, ev dışı gıda tüketim sıklığı arasında anlamlı fark (\%99 güven aralığında) vardır. Sağlıklı beslenme ile cinsiyet, çalışma, yaş ve ev dışı gıda tüketim sıklığı arasında fark \%99 güven aralığında anlamlı olarak bulunmuştur. Değişkenlerin ortalamalarına bakıldığında sağlıklı beslenme ve gıda seçiciliği konusunda çalışanların lehine anlamlı fark hesaplanmıştır. Her ne kadar cinsiyet açısından anlamlı fark olmasa da çalışan erkeklerde sağlıklı beslenme algısı kadınlara göre pozitif bulunmuştur.

Tablo 5. Gıda satın alma grup değişkenleri ve güvenilirlik değerleri

\begin{tabular}{lrr}
\hline & \multicolumn{2}{c}{ Component } \\
\hline $\begin{array}{l}\text { Gıda ürünlerinin üretim yeri benim için önemlidir (yerli ya da ithal } \\
\text { olması) }\end{array}$ & Gıda seçiciliği & Sağlıklı beslenme \\
\hline Yediğim yiyeceklerin organik ürün olması önemlidir &, 868 \\
\hline Sağlığıma çok dikkat ederim ve buna göre beslenirim &, 779 \\
\hline Bir gıda ürünü alırken mutlaka son kullanma tarihine bakarım &, 709 \\
\hline Alışkanlıklarımı zor değiştiririm &, 691 \\
\hline Yaptığım seyahatlerde mutlaka yöresel bir ürünün denerim &, 632 \\
\hline Doğru ürünü seçebilirim &, 555 \\
\hline Yemek seçiciliğim vardır &, 543 &, 902 \\
\hline Prebiyotik/probiyotik/sporcu içeceği gibi gidaların faydasına inanırım &, 871 \\
\hline Gıda takviyesi kullanmaktan çekinmem & &, 721 \\
\hline Promosyonları olan fast-food restoranlarında yemeyi tercih ederim &, 541 \\
\hline Yemek yerken TV seyrederim ya da tlf vb. mobil cihazlarla ilgilenirim & & 2,33 \\
\hline Özdeğer & & 19,407 \\
Varyans & & 0,772 \\
Cronbach's Alpha & 3,30 & \\
\hline
\end{tabular}

Extraction Method: Principal Component Analysis.

Rotation Method: Varimax with Kaiser Normalization.

a. Rotation converged in 3 iterations.

Tablo 6. Test istatistikleri Hipotez test değişkenleri

\begin{tabular}{lcccc}
\hline & $\begin{array}{c}\text { Faktör 1 } \\
\text { Gida seçiciliği } \\
\text { Sig. }\end{array}$ & $\begin{array}{c}\text { Hipotez } \\
\text { Ret/Kabul }\end{array}$ & $\begin{array}{c}\text { Faktör 2 } \\
\text { Sağllkl } \\
\text { beslenme Sig }\end{array}$ & $\begin{array}{c}\text { Hipotez } \\
\text { Ret/Kabul }\end{array}$ \\
\hline Cinsiyet ile fark anlamlı değildir* & 0,098 & Kabul & 0,000 & Ret \\
Calışma durumu ile fark anlamlı değildir* & 0,014 & Ret & 0,001 & Ret \\
Eğitim ile fark anlamlı değildir** & 0,002 & Ret & 0,052 & Kabul \\
Yaş ile fark anlamlı değildir** & 0,204 & Kabul & 0,003 & Ret \\
Gelir ile fark anlamlı değildir** & 0,000 & Ret & 0,119 & Kabul \\
Ev dışı tüketim sılklı̆ğ ile fark anlamlı değildir** & 0,000 & Ret & 0,000 & Ret \\
\hline
\end{tabular}


Eğitim gruplarının anlamlılığı da yeniden her grup arasındaki ilişkiye bakılarak test edilmiş, üniversite ve lisansüstü eğitim alanların diğer gruplara göre gida seçiciliğinde farklılık gösterdiği belirlenmiştir. Yaş gruplarında ise 25 yaş ve üzerinde sağlıklı beslenme algısı pozitif bulunmuştur. Gıda seçiciliğinde, gelir istatistiki olarak anlamlıdır ve gelir arttıkça gıda seçiciliği de artmaktadır. Bu farklılık bir ve ikinci gelir grupları aleyhinde anlamlılık göstermektedir. Ev dışı gıda tüketim sıklığı ile gıda seçiciliği ve sağlıklı beslenme istatistiksel olarak anlaml farklılıklar göstermektedir. $\mathrm{Bu}$ anlamlılık çalışanlar lehine özellikle günlük ve haftada birkaç gün ev dışında yemek yeme sıklığında belirgindir. Benzer sonuçlar gelir ile de ortaya çıkmıştır. Özellikle geliri 1500 TL üzerinde olan gruplarda haftada birkaç kez ev dışı gıda tüketimi çoğunlukla tercih edilmektedir. Her ne kadar gelir arttıkça ev dışı gıda tüketimi artsa da sağlıklı yaşam ve bunun bir parçası olan beslenme ile ilgili kaygılar da artmaktadır. Bu da sağlıklı beslenme kriterleri içinde yer alan geleneksel ev yemeklerinin tüketimi, yemek saatinin belirli zaman aralığında olması, ara öğün ve ana öğünlerin dengede tutulması gibi rutinlerin uygulanmasını zorunlu kılmaktadır. Ayrıca, aile ile birlikte yaşam da ev dışı gida tüketiminde etkili bir faktördür. Nitekim çalışmada da 9 yaşından küçükler ile 27 yaşından büyük katılımcıların daha az sıklıkla ev dışında yemek yediği ve sağlıklı beslenme konusunda daha duyarlı olduğu ilişkisi belirlenmiştir. Kılıç ve Şanlıer (2007) üç kuşak kadının yemek alışkanlığını araştırdıkları çalışmalarında Y kuşağında yer alan 3. Kuşak aile bireyi kadınların ev dışı yemek alışkanlığının daha yüksek olduğunu ve de dengesiz beslenme olarak değerlendirile bilecek öğun atlama, simit/poğaça gibi unlu mamuller ile kahvaltı yapma alışkanlıklarını önemli oranda diğer kuşaklardan farklı bulmuşlardır. Traş ve Şengül (2017) e çalışmalarında Y kuşağını da içine alan yaş gruplarında ev dışı yemek yemede yaşın pozitif ve anlamlı bir etkisi olduğunu belirlemişlerdir.

\section{SONUÇ}

Tüketici davranışlarını anlayabilmek amaçlı tüketicileri temsil eden kuşakları sistematik olarak ele almak bilim dünyasının kabul gördüğü bir yoldur. Bu ön kabul ile kuşaklar incelendiğinde günümüzde nüfus olarak en kalabalık kuşağın Y kuşağıdır. Nitekim büyük tüketici ve insan kaynağı kitlesi olan Y kuşağ özellikle turizm, eğitim, tüketim, teknoloji, sosyal medya kullanımı, insan kaynakları ve girişimcilik konularında araştırmacıların ve karar alıcıların çalışmalarında yoğunluğu oluşturmuştur. Diğer alanlara kıyasla Y kuşağının gıda tüketimleri üzerine daha az çalışma vardır. Bu çalışma ile Y kuşağının gıda tüketim alışkanlıkları ve tercihlerini belirleme ve tercihlerinde etkili olan faktörleri ortaya koymak amacıyla Adana şehir merkezinde yaşayan 1980-2000 doğumlu 300 kişiyle anket yapılmıştır. Ankete katılanların öğün tercihlerinde belirgin bir ortak tercihin olduğu; unlu mamuller/pastacıllk ürünlerinin sabah öğününde $(\% 66,8)$; fast food ürünlerinin öğlen $(\% 40,3)$ ve geleneksel mutfak ürünlerinin (\%65) tüketildiği belirlenmiştir.

Katılımcıların gıda seçiciliği ve sağlıklı beslenme olarak nitelendirilen algı ve davranışları içine alan faktörlerde gıda seçiciliği ile çalışma, eğitim, gelir, ev dışı gıda tüketim sıklığı arasında anlamlı fark elde edilirken, sağlıklı beslenme ile de cinsiyet, çalışma, yaş ve ev dışı gıda tüketim sıklığı arasındaki fark anlamlı olarak bulunmuştur. İletişim araçlarının yayginlaşması ile bilgiye ulaşma ve paylaşma, toplum refahı için kitlesel düzeyde yapılan çalışmalar ve uygulamalar son yıllarda sağlık kaygısı ve buna bağlı olarak sağlıklı beslenme olgusunu artırmıştır. Birçok çalışma da tüketicilerin sağlıklı beslenme algılarının pozitif yönlü olduğunu ortaya koymaktadır. Y kuşağını içine alan yaş grupları ile yapılan çalışmalarda sağlıklı beslenme eğilimi ve algisının belirgin olduğu İkikat'ın (2018) çalışmasında da vurgulanmıştır. Bu bulgular ve çalışmalarla birlikte, tüketicilerin algıları, sağlıklı beslenmeye yönelik tutumları ile tutarlı değildir. Bu çalışmada bir yandan gıda seçiciliği öne çıkarken bir yandan da sağlıklı beslenme algısının yaygın olduğu söylenebilirken diğer yandan öğün tercihleri ve yemek alışkanlıkları bakımından tutumların aynı olmadığı gerçeği öne çıkmıştır. Fast-food ve unlu mamul gibi hazır ve hizlı tüketimi olan ürün tüketimlerinin belirgin olması, sebze, tahıl ve Akdeniz mutfağı gibi sağllklı beslenmede önemi vurgulanan ürünlerin daha az tercih edilir olmass bu anlamda ipucu veren bulgular olmuştur. Bu bulgular, genç yetişkinleri içine alan Y kuşağı için sürdürülebilir, sağlıklı ve aynı zamanda geleneksel Türk mutfağının tüketimini teşvik etmek için karar alıcılar ve gıda pazarlaması paydaşları için kısıtlı da olsa bilgi verici niteliktedir. Bu çalışma, sadece Y kuşağını ele alıp bir önceki ve bir sonraki kuşak olan $\mathrm{X}$ ve $\mathrm{Z}$ kuşaklarını dışarıda bırakması açısından kısıtlar da içermektedir. Daha sonra planlanacak çalışmalarda birkaç kuşağın ele alınıp karşılaştırmaların yapılması geniş planlama ve müdahale alanı için sonuçlar verebilir.

\section{TEŞEKKÜR}

Bu çalışma, Adana Bilim ve Teknoloji Üniversitesi, BAP-17113009 nolu proje sonuçlarını içermektedir.

\section{KAYNAKLAR}

Adıgüzel O, Batur HZ, Ekşili N 2014. Kuşakların değişen yüzü ve $\mathrm{Y}$ kuşağı ile ortaya çıkan yeni çalışma tarzı: Mobil yakalılar. Süleyman Demirel Üniversitesi Sosyal Bilimler Enstitüsü Dergisi, 1(19): 165-182.

Akdemir A, Konakay G 2014. Y Kuşağının Kariyer Algısı, Kariyer Değişimi Ve Liderlik Tarzı 
Beklentilerinin Araştırılması. Muğla Sitkı Koçman Üniversitesi İktisadi Ve İdari Bilimler Fakültesi Ekonomi ve Yönetim Araştırmaları Dergisi, 2(2):11-42.

Akten M 2016. Y ve Z Kuşaklarının Turizm Algıları ve Konaklama İşletmelerinden Beklentileri, Balıkesir Üniversitesi Sosyal Bilimler Enstitüsü Turizm İşletmeciliği ve Otelcilik Anabilim Dalı Yüksek Lisans Tezi, $136 \mathrm{~s}$.

Altundağ N 2012. "Kuşaktan Kuşağa Tüketim Olgusu ve Geleceğin Tüketici Profili", Organizasyon ve Yönetim Bilimleri Dergisi. 1:203-212.

Bakewell C, Mitchell VW 2003. Generation Y Female Consumer Decision-Making Styles. International Journal of Retail and Distribution Management, 31(2): 95-106.

Bakis O 2017. Kuşaklar arası eğitim hareketliliği: ABTürkiye karşılaştırması, Finans Politik\& Ekonomik Yorumlar. 54(634):97-105.

Baran A 2018. X ve Y Kuşağı Mensubu Satış Danışmanlarının Motivasyon Faktörleri Arasındaki Farklılıklar; Otomotiv Sektöründe Bir Araştırma, Maltepe Üniversitesi, Sosyal Bilimler Enstitüsü, İşletme ABD, Yüksek Lisans Tezi, 98 s.

Basgöze P, Bayar NA 2015. Eko Otellerden Hizmet Satin Aliminda Kusaklar Arasi Farklilasmalar Üzerine Bir Çalisma/A Study Based on the Generation Differentiations Concerning Service Purchase Intentions for Eco-Hotels. Sosyoekonomi, (2):118.

Bayhan V 2014. Milenyum veya (Y) Kuşağ Gençliğinin Sosyolojik Bağlamı. Gençlik Araştırmaları Dergisi, 2(3): 8-25.

Bayrakdaroğlu F, Çakır H 2016. Tüketicilerin Online Alışverişlerine İlişkin Karar Alma Tarzlarının İncelenmesine Yönelik Bir Araştırma-A Research Towards Consumers' Decision-Makıng Styles Regarding Onlıne Purchasing Behavior. Mehmet Akif Ersoy Üniversitesi Sosyal Bilimler Enstitüsü Dergisi, 8(15): 266-284.

Berkup SB 2014. Working With Generations X And Y in Generation Z Period: Management of Different Generations In Business Life. Mediterranean Journal of Social Sciences, 5(19): 218-229.

Bilgihan A 2016. Gen Y customer loyalty in online shopping: An integrated model of trust, user experience and branding. Computers in Human Behavior. 61:103-113.

Bilgihan A, Okumus F, Cobanoglu C 2013. Generation Y travelers' commitment to online social network websites. Tourism Management, 35:13-22.

Bolton RN, Parasuraman A, Hoefnagels A, Migchels N, Kabadayi S, Gruber T, Solnet D 2013. Understanding Generation Y and their use of social media: a review and research agenda. Journal of service management, 24(3): 245-267.

Braunstein JR, Zhang JJ 2005. Dimensions of athletic star power associated with Generation Y sports consumption. International Journal of Sports Marketing and Sponsorship, 6(4):37-62.

Büyük SS 2005. "Biz Kuşağı Geliyor". Capital. https://www.capital.com.tr/ ekonomi/makroekonomi/biz-kusagi-geliyor College Students", Journal of Advertising Research, 41:33-52.

Casalo L, Flavian C, Guinaliu M 2008. The role of usability and satisfaction in the consumer's commitment to a financial services website. International Journal of Electronic Finance, 2(1):31-49.

Chuah S HW, Marimuthu M, Kandampully J, Bilgihan A 2017. What drives Gen Y loyalty? Understanding the mediated moderating roles of switching costs and alternative attractiveness in the valuesatisfaction-loyalty chain. Journal of Retailing and Consumer Services. 36:124-136.

Çetin A, Alacalar A 2016. "İş Yaşamında Yalnızlı̆̆ Yordomada Kişilik Özellikleri ile Algılanan Sosyal ve Örgütsel Desteğin Rolü”, Uluslararası Yönetim İktisat ve İşletme Dergisi, 12(27):193-216.

Çetin C, Karalar S 2016. "X, Y ve Z Kuşağ Öğrencilerin Çok Yönlü ve Sınırsız Kariyer Algıları Üzerine Bir Araştırma”, Yönetim Bilimleri Dergisi, 14(28):157-197.

Çinkılıç MA 2018. X Ve Y Kuşağı Mensubu Öğretmenlerin Mesleki Etik Algılarının Karşılaştırılmasına İlişskin Bir Alan Araştırması, Hitit Üniversitesi Sosyal Bilimler Enstitüsü İşletme ABD, Yüksek Lisans Tezi, $86 \mathrm{~s}$.

Danışman ŞA, Gündüz Ş 2018. X ve Y Kuşaklarının Dişarıdan Kahvaltı Satın Alma Davranış Farklılıkları, Atatürk Üniversitesi Sosyal Bilimler Enstitüsü Dergisi, 22(Özel Sayı): 707-728

Demirkaya H, Akdemir A, Karaman E, Atan Ö 2015. Kuşakların yönetim politikası beklentilerinin araştırılması, İşletme Araştırmaları Dergisi, 7(1): 186-204

Dereli B, Toruntay H 2015. Örgütlerde kuşakların iş değerleri, motivasyon ve mentorluk kavramlarına dayalı yönetimi. İstanbul Ticaret Üniversitesi, Dış Ticaret Enstitüsü, Tartı̧̧ma Metinleri, (03); 05.

Dhanapal S, Vashu D, Subramaniam T 2015. "Perceptions on the Challenges of Online Purchasing: a Study from "Baby Boomers", Generation "X" and Generation "Y" Point of Views". Contaduría y Administracion, 60(1): 107-132.

Djamasbi S, Siegel M, Tullis T 2010. Generation Y, web design, and eye tracking. International journal of human-computer studies, 68(5): 307-323.

Doğan S, Yücel Güngör M, Güngör O 2018. Yiyecekİçecek Hizmetlerinin Değerlenmesinde Kuşaklararası Farkların Belirlenmesi: LaraKundu Otelleri Üzerine Bir Araştırma. Güncel Turizm Araştırmaları Dergisi, 2 (Ek1): 616-629.

Dursun MT, Eriş ED 2018. Konaklama işletmelerinde kuşaklar bağlamında işveren marka algısı ile 
çalışma yaşam kalitesi ilişkisi. Nevşehir Hacı Bektaş Veli Üniv. SBE Dergisi, 8(1): 160-179.

Duvendack CM 2010. Correlation of Work-Life Balance Decisions of Different Generations of Physicians. (Unpublished PhD. Thesis). USA: Capella University.

Engizek N, Şekerkaya A, 2016. X Ve Y Kuşağı Kadınlarının Karar Verme Tarzları Bakımından İncelenmesi, Mustafa Kemal Üniversitesi Sosyal Bilimler Enstitüsü Dergisi, 13(36): 242-271

Erdirençelebi M 2012. Aile İşletmelerinde Kurumsallaşmanın Gerçekleşmesi Ile Sürdürülebilirliğin Sağlanmasında Kuşaklar Arası Farklılıklar, Selçuk Üniversitesi, Sosyal Bilimler Enstitüsü, İşletme ABD, Doktora Tezi, 491 s.

Etlican G 2012. X ve Y Kuşaklarının Online Eğitim Teknolojilerine Karşı Tutumlarının Karşılaştırılması, Bahçeşehir Üniversitesi, Sosyal Bilimler Enstitüsü, Insan Kaynakları Yönetimi ABD, Yayınlanmış Yüksek Lisans Tezi, 63 s.

Foscht T, Schloffer J, Maloles III C, Chia SL 2009. Assessing the outcomes of Generation-Y customers' loyalty. International Journal of Bank Marketing, 27(3): 218-241.

Galentıne E 2013. "Managing Millennials", employeebenefitadiser.com, 56-57.

Giovannini S, Xu Y, Thomas J 2015. Luxury fashion consumption and Generation Y consumers: Self, brand consciousness, and consumption motivations. Journal of Fashion Marketing and Management, 19(1): 22-40.

Gurău C 2012. A life-stage analysis of consumer loyalty profile: comparing Generation $\mathrm{X}$ and Millennial consumers. Journal of consumer Marketing, 29(2): 103-113.

Gürbüz S 2015. "Kuşak Farklılıkları: Mit mi, Gerçek mi?”. İş ve İnsan Dergisi, 2(1): 39-57.

Hanzaee KH, Aghasibeig S 2008. Generation Y female and male decision-making styles in Iran: are they different?. The International Review of Retail, Distribution and Consumer Research, 18(5): 521537

Hole D, Zhong L, Schwartz J 2010. "Talking about Whose Generation? Why Western Generational Models Can't Account for a Global Workforce". Deloitte Review, 6: 84-97.

Holtzhausen T, Strydom J 2006. Generation Y consumers: Behavioural patterns of selected South African students. The Business Review Cambridge, 5(1): 314-318.

İkikat Tümer E 2018. Lise ve Dengi Okullardaki Öğrencilerin Fast Food Tüketim Kararları. KSÜ Doğa Bilimleri Dergisi, 21(1): 1-6.

Ilğaz M 2018. Kuşaklar Arası Hedonik Tüketim Davranışlarının Demografik Özelliklere Göre Farklılıkları: Kastamonu İli Merkez İlçesi Üzerine Bir Araştırma. Turkısh Journal Of Marketıng, 3(1):1-17
İşçimen DS 2012. Y Kuşağı Çalışanların İş Yaşamından Beklentilerinin Karşılanma Düzeyi ile Kurumsal Bağlılık Arasındaki İlişki ve Bir Örnek Uygulama. Bahçeşehir Üniversitesi, Sosyal Bilimler Enstitüsü, İnsan Kaynakları Yönetimi ABD. Yayımlanmamış Doktora Tezi, $111 \mathrm{~s}$.

Jingxiong J, Rosenqvist U, Huishan W, Greiner T, Guangli L, Sarkadi A 2007. Influence of grandparents on eating behaviors of young children in Chinese three-generation families. Appetite, 48(3): 377-383.

Karabekir M, Nur M, Şencan M, Tozlu E 2016, Y Kuşağının Girişimcilik Algısının Ölçümüne Yönelik Bir Araştırma, International Journal Of Academic Values Studies, (4): 59-67.

Kavalcı K, Ünal S 2016. Y ve Z Kuşaklarının Öğrenme Stilleri ve Tüketici Karar Verme Tarzları Açısından Karşılaştırılması. Atatürk Üniversitesi Sosyal Bilimler Enstitüsü Dergisi, 20(3):1033-1050

Keleş HN 2013. Girişimcilik Eğiliminin Kuşak Farkına Göre İncelenmesi, Selçuk Üniversitesi İktisadi İdari Bilimler Fakültesi Sosyal Ve Ekonomik Araştırmalar Dergisi, 13(26):23-43

Khalek AA, Ismail SHS 2015. Why Are We Eating Halal-Using the Theory of Planned Behavior in Predicting Halal Food Consumption among Generation Y in Malaysia. International Journal of Social Science and Humanity, 5(7): 608-612.

Kılıç E, Şanlıer N 2007. Üç kuşak kadınının beslenme alışkanlıklarının karşılaştırılması. Kastamonu Eğitim Dergisi, 15(1): 31-44.

Kılıç HA, Kılıç S 2017. Y Kuşağı Tüketicilerinin Alışveriş Stilleri: Cinsiyete Göre Bir Araştırma. Kırklareli Üniversitesi İktisadi ve İdari Bilimler Fakültesi Dergisi, 6(4): 61-72.

Kim D, Jan S. 2014. "Motivational Drivers for Status Consumption: A Study of GenerationY Consumers". International Journal of Hospitality Management, 38: 39-47.

Konyar H 2017. Etik Gıda Tüketiminde Yaşa Bağlı Olarak Ortaya Çıkan Beğeni Tercihleri: İstanbul'da Etnografik Alan Çalışması. Senex: Yaşlılık Çalışmaları Dergisi, 1 (1): 33-47.

Köse S, Oral L, Tetik HT 2014. "Y kuşağının birinci ve ikinci yarısında iş değerlerinin karşılaştırılması üzerine bir araştırma”. Humanitas, 2(3): 149-165.

Kumar A, Lim H 2008. Age differences in mobile service perceptions: Comparison of Generation Y and Baby Boomers. Journal of Services Marketing, 22(7): 568-577.

Kuyucu M. 2017. Y Kuşağı ve Teknoloji: Y Kuşağının Illetişim Teknolojilerini Kullanım Alışkanlıkları. Gümüşhane Üniversitesi İletişim Fakültesi Elektronik Dergisi, 5(2): 845-872.

Kwon O, Wen Y 2010. An empirical study of the factors affecting social network service use. Computers in human behavior, 26(2): 254-263. 
Lazarevic V 2012. Encouraging brand loyalty in fickle generation Y consumers. Young consumers, 13(1): $45^{-61 .}$

Lazarevic V, Petrovic-Lazarevic S 2007. Increasing brand loyalty of generation $\mathrm{Y}$ for future marketers. Availiable at: http://www. buseco. monash. edu. $\mathrm{au} / \mathrm{mgt} /$ research/working-papers/2007/wp28-07. pdf.

Lester DH, Forman AM, Loyd D 2006. Internet shopping and buying behavior of college students. Services Marketing Quarterly, 27(2): 123138.

Levickaite R 2010. "Generations X Y Z: How social networks form the concept of the world without borders the case of Lithuania" LIMES: Cultural Regionalistics, 173

Ling KC, Mun YW, Ling HM 2011. Exploring factors that influence customer loyalty among Generation $\mathrm{Y}$ for the fast food industry in Malaysia. African Journal of Business Management, 5(12): 48134823.

Lissitsa S, Kol O 2016. Generation X vs. Generation YA decade of online shopping. Journal of Retailing and Consumer Services, 31: 304-312.

Mandhlazi L, Dhurup M, Mafini C 2013. Generation Y consumer shopping styles: evidence from South Africa. Mediterranean Journal of Social Sciences, 4(14): 153-164.

Martin CA, Turley LW 2004. Malls and consumption motivation: an exploratory examination of older generation Y consumers. International Journal of Retail \& Distribution Management, 32 (10): 46475.

Mengi Z 2017. İş Başarısında Kuşak Farkı, http://www.kigem.com/content.asp?bodyID $=4962$, (Erişim tarihi: 13. Eylül. 2017).

Morsümbül Ş 2014, Değerlerin Kuşaklar Arası Değişimi: Ankara Örneği, Hacettepe Üniversitesi Sosyal Bilimler Enstitüsü Sosyoloji ABD, Doktora Tezi, $204 \mathrm{~s}$.

Mücevher MH 2015. X ve Y Kuşağının Birbirlerine Karşı Özellik ve Etkileşim Algıları: SDÜ Örneği. Isparta: Süleyman Demirel Üniversitesi Sosyal Bilimler Enstitüsü, İşletme ABD, Yüksek Lisans Tezi, $168 \mathrm{~s}$.

Noble SM, Haytko DL, Phillips J 2009. What drives college-age Generation Y consumers?. Journal of business research, 62(6): 617-628.

Nusair K, Bilgihan, A, Okumus F 2013. The role of online social network travel websites in creating social interaction for Gen Y travelers. International journal of tourism research, 15(5): 458-472.

O'Donnell J 2006. Gen Y sits on top of consumer food chain; they're savvy shoppers with money and influence. USA Today, 11(2): 322-358.

O'Cass A, Choy E 2008. Studying Chinese generation $\mathrm{Y}$ consumers' involvement in fashion clothing and perceived brand status. Journal of Product \& Brand Management, 17(5): 341-352.

Ordun G 2015. "Millennial (Gen Y) Consumer Behavior, Their Shopping Preferences and Perceptual Maps Associated with Brand Loyalty". Canadian Social Science, 11(4): 40-55.

Özer AC 2008. Gıda Sektöründe Marka İmajının Tüketici Satın Alma Davranışı Üzerine Etkisi ve Bir Uygulama. Muğla Üniversitesi, Sosyal Bilimler Enstitüsü, İşletme ABD, Yüksek Lisans Tezi, 137 s.

Parment A 2013. Generation Y vs. Baby Boomers: Shopping behavior, buyer involvement and implications for retailing. Journal of retailing and consumer services, 20(2): 189-199.

Pekmezci P 2017. Ailelerin Etnosentrik Gıda Ürünleri Tüketim Davranışları: Kuşaklararası Bir Inceleme. Hacettepe Üniversitesi, Sosyal Bilimler Enstitüsü, Aile ve Tüketici Bilimleri ABD, Yüksek Lisans Tezi, $112 \mathrm{~s}$.

Petra KK 2016. "Generation Y Attitudes towards Shopping: A Comparison of the Czech Republic and Slovakia”. Journal of Competitiveness, 8(1): 38-54.

Rahulan M, Troynikova O, Watsona C, Jantab M, Sennerb V 2013. "Consumer Purchase Behaviour of Sports Compression Garments: A Study of Generation Y and Baby Boomer Cohort"s. Procedia Engineering, 60: 163-169.

Reeves TC, Oh E 2008. Generational differences, in handbook of research on educational communications and technology, p. 296, Third Edition Selected South African Students", The Business Review Cambridge, 5: 314-318.

Rhodes K, Chan F, Prichard I, Coveney J, Ward P, Wilson C 2016. Intergenerational transmission of dietary behaviours: a qualitative study of AngloAustralian, Chinese-Australian and ItalianAustralian three-generation families. Appetite, 103: 309-317.

Sarı S, Gürsoy S, Özmen M 2016. Y Kuşağının Çevrim İçi Satın Alma Davranışları. Bitlis Eren Üniversitesi Sosyal Bilimler Enstitüsü Dergisi, 5(1): 87-104.

Sarıtaş E, Barutçu S 2016. Tüketici Davranışlarının Analizinde Kuşaklar: Sosyal Medya Kullanımı Üzerinde Bir Araştırma, Pamukkale Journal of Eurasian Socioeconomic Studies, 3(2):1-15

Traş MF, Şengül S 2017. Cohort Effect on Food Away From Home in Turkey: A Double Hurdle Approach: In Beloved Memory of Dr. MEHMET FATIH TRAŞ. Akdeniz Universitesi Iktisadi ve Idari Bilimler Fakultesi Dergisi, 17(35): 59-80

Sharifi FS, Tamam E, Hj Hassan MS, Waheed M, Zaremohzzabieh Z 2016. Factors affecting Malaysian university students' purchase intention in social networking sites. Cogent Business \& Management, 3(1): 1-12.

Shim S, Serido J, Barber BL 2011. A consumer way of thinking: linking consumer socialization and 
consumption motivation perspectives to adolescent development. Journal of Research on adolescence, 21(1): 290-299.

Spector JM, Merril M.D, Merrienboer JV, Driscoll MP (Eds). NewYork: Taylor \& Francis Group.

Stafleu A, Van Staveren WA, de Graaf C, Bure J, Hautvast JG 1995. Family resemblance in beliefs, attitudes, and intentions towards consumption of 20 foods; a study among three generations of women. a Study Among Three Generations of Women. Appetite, 25(3): 201-216.

Stafleu A, Van WS, De CG, Burema J, Hautvast JG 1996. Nutrition knowledge and attitudes towards high-fat foods and low-fat alternatives in three generations of women. European Journal of Clinical Nutrition, 50(1): 33-41.

Sullivan P, Heitmeyer J 2008. Looking at Gen Y shopping preferences and intentions: exploring the role of experience and apparel involvement. International Journal of Consumer Studies, 32(3): 285-295.

Tabachnick BG, Fidell LS 2015. Çok değişkenli istatistiklerin kullanımı. Çev. Edt. M. Baloğlu). Ankara: Nobel Yayın Dağıtım.

Tingley C 2015. Social Media Marketing Strategies to Engage Generation Y Consumers (Doctoral dissertation). Available from ProQuest Dissertations and Theses database. (UMI No. 1696711650)

Toruntay H. 2011. Takım Rolleri Çalışması: X ve Y Kuşağı Üzerinde Karşılaştırmalı Bir Araştırma. İstanbul Üniversitesi Sosyal Bilimler Enstitüsü İsletme Anabilim Dalı, Yüksek Lisans Tezi, $130 \mathrm{~s}$.

Tükel İ 2014. Tüketimin Yeni Aktörleri. Y Kuşağı”, http://www. sdergi. hacettepe. edu. tr/makaleler/Tuketim-Yeni Aktor Y kusagi. Kasım.

Ustakara F, Türkoğlu E 2015. Y kuşağının bir gözetim mekanizması olarak sosyal ağlar üzerine algısı: Gaziantep Üniversitesi araştırması. Turkish
Studies-International Periodical for the Languages, Literature and History of Turkish or Turkic, 10, 10. Value Studies 2 (3): 59-67.

Valentine DB, Powers TL 2013. Online product search and purchase behavior of Generation Y. Atlantic Marketing Journal, 2(1): 76-90.

Vermeir I, Verbeke W 2008. Sustainable food consumption among young adults in Belgium: Theory of planned behaviour and the role of confidence and values. Ecological economics, 64(3): 542-553.

Williams CK, Page AR 2011. "Marketing to the Generations". Journal of Behavioral Studies in Business. 3: 3-11.

Wolburg J, Pokrywczynski J 2001. "A Psychographic Analysis of Generation Y College Students", Journal of Advertising Research, 41: 33-52.

Yang FX, Lau VM 2015. "LuXurY" hotel loyalty-a comparison of Chinese Gen X and Y tourists to Macau. International Journal of Contemporary Hospitality Management, 27(7): 1685-1706.

Yaşa E, Bozyiğit S 2012. Y Kuşağı Tüketicilerinin Cep Telefonu Ve Gsm Operatörleri Tercihi: Mersin İlindeki Üniversite Öğrencilerinin Tercihlerini Belirlemeye Yönelik Pilot Bir Araştırma. Cag University Journal Of Social Sciences, 9(1):29-46

Yazıcıoğlu Y, Erdoğan S 2004. SPSS Uygulamalı Bilimsel Araştırma Yöntemleri. Ankara: Detay Yayıncılık.

Yüksekbilgili Z 2013. "Türk Tipi Y Kuşă̆ı". Elektronik Sosyal Bilimler Dergisi, 12(45): 342-353.

Yüksekbilgili Z 2015. Türkiye'de Y Kuşağının Yaş Aralığı, Elektronik Sosyal Bilimler Dergisi, 14(53): 259-267

Zemke R, Raines C, Filipczak B 2000. Generations at Work: Managing the Clash of Veterans, Boomers, Xers, Nexters in Your Workplace, Publisher: AMACOM Books 